\title{
Insulin resistance and diabetes mellitus in transgenic mice expressing nuclear SREBP-1c in adipose tissue: model for congenital generalized lipodystrophy
}

\author{
Iichiro Shimomura, ${ }^{1,4}$ Robert E. Hammer, ${ }^{2,4}$ James A. Richardson, ${ }^{3}$ Shinji Ikemoto, ${ }^{1}$ \\ Yuriy Bashmakov, ${ }^{1}$ Joseph L. Goldstein, ${ }^{1,5}$ and Michael S. Brown ${ }^{1}$ \\ ${ }^{1}$ Department of Molecular Genetics, ${ }^{2}$ Department of Biochemistry and Howard Hughes Medical Institute, ${ }^{3}$ Department \\ of Pathology, The University of Texas Southwestern Medical Center at Dallas, Dallas, Texas 75235 USA
}

\begin{abstract}
Overexpression of the nuclear form of sterol regulatory element-binding protein-1c (nSREBP-1c/ADD1) in cultured 3T3-L1 preadipocytes was shown previously to promote adipocyte differentiation. Here, we produced transgenic mice that overexpress nSREBP-1c in adipose tissue under the control of the adipocyte-specific aP2 enhancer/promoter. A syndrome with the following features was observed: (1) Disordered differentiation of adipose tissue. White fat failed to differentiate fully, and the size of white fat depots was markedly decreased. Brown fat was hypertrophic and contained fat-laden cells resembling immature white fat. Levels of mRNA encoding adipocyte differentiation markers $(C / E B P \alpha, P P A R \gamma$, adipsin, leptin, UCP1) were reduced, but levels of Pref-1 and TNF $\alpha$ were increased. (2) Marked insulin resistance with 60-fold elevation in plasma insulin. (3) Diabetes mellitus with elevated blood glucose $(>300 \mathrm{mg} / \mathrm{dl})$ that failed to decline when insulin was injected. (4) Fatty liver from birth and elevated plasma triglyceride levels later in life. These mice exhibit many of the features of congenital generalized lipodystrophy (CGL), an autosomal recessive disorder in humans.
\end{abstract}

[Key Words: SREBP; adipose tissue; diabetes mellitus; insulin resistance; congenital generalized lipodystrophy]

Received August 13, 1998; revised version accepted August 26, 1998.

Congenital generalized lipodystrophy (CGL) was delineated by Seip (1959) in studies of three children, two of whom were siblings. Subsequently, $>100$ patients with this developmental disorder have been described, and the syndrome has been well characterized clinically (Seip and Trygstad 1996). Affected individuals are born with an extreme paucity of white fat, and they exhibit profound insulin resistance, hyperinsulinemia, hyperglycemia, an enlarged fatty liver, and varying degrees of hypertriglyceridemia. Secondary features include a voracious appetite, hypermetabolism, and an anabolic syndrome that includes organomegaly (pancreas, spleen, kidneys), rapid height development, and hypertrophy of skeletal and cardiac muscle. Inheritance is autosomal recessive. The underlying cause is unknown, and no mouse model has been developed. An understanding of the pathogenesis of this syndrome might provide insights into the much more common forms of insulin resistance that occur in obese individuals and lead to noninsulin-dependent diabetes mellitus.

One of the transcription factors that has been impli-

\footnotetext{
${ }^{4}$ These authors contributed equally to this work.

${ }^{5}$ Corresponding author.

E-MAIL jgolds@mednet.swmed.edu; FAX (214) 648-8804.
}

cated in adipose differentiation is sterol regulatory element-binding protein-1c (SREBP-1c), one of three SREBPs found in animal cells (Tontonoz et al. 1993; Yokoyama et al. 1993). The SREBP family of proteins was purified and cloned in our laboratory on the basis of their ability to bind and activate the promoters of genes involved in cholesterol biosynthesis and uptake (for review, see Brown and Goldstein 1997). The SREBP-1c cDNA was isolated independently by Spiegelman and coworkers in an expression screen for proteins that bind to an E-box sequence in the promoter of fatty acid synthase (Tontonoz et al. 1993; Kim and Spiegelman 1996). This cDNA was shown to exert effects on fatty acid synthesis and differentiation of mouse 3T3-L1 adipocytes in tissue culture, and, hence, the protein was named adipocyte determination and differentiation factor-1 (ADD-1).

The SREBPs are unique among transcription factors because they are synthesized as membrane-bound precursors. Each SREBP comprises $\sim 1100$ amino acids that are organized in three domains (Brown and Goldstein 1997). The amino-terminal domain of $\sim 500$ amino acids is a transcription factor of the basic-helix-loop-helix leucine zipper family. This is followed by a membrane attachment domain and a carboxy-terminal regulatory domain. To activate transcription, the amino-terminal 
domains of the SREBPs must be released from membranes of the endoplasmic reticulum (ER) so that they can enter the nucleus. Release is accomplished by two proteases that cut the SREBPs in obligatory order at site 1 and site 2 . The site 1 protease is subject to feedback regulation by cholesterol. When cellular sterol levels are low, this protease is activated, and the amino-terminal domains enter the nucleus. When sterols accumulate in cells, the Site-1 protease is inactivated, and the SREBPs remain bound to extranuclear membranes. This control mechanism assures a constant supply of cholesterol and fatty acids while preventing overaccumulation.

The amino-terminal domains of the SREBPs /designated nSREBPs) are dual-specificity transcription factors that bind to nonpalindromic sterol regulatory elements as well as to palindromic E boxes (Yokoyama et al. 1993; Kim et al. 1995; Párraga et al. 1998). They turn on the entire program of cholesterol and fatty acid biosynthesis by activating transcription of multiple genes encoding enzymes of these pathways (Brown and Goldstein 1997). In the cholesterol biosynthetic pathway, the documented direct targets of nSREBPs include 3-hydroxy-3methylglutaryl coenzyme A (HMG CoA) synthase, HMG CoA reductase, farnesyl diphosphate synthase, and squalene synthase. Targets in the fatty acid biosynthetic pathway include acetyl CoA carboxylase and fatty acid synthase. In addition, the nSREBPs activate transcription of the low-density lipoprotein (LDL) receptor, which mediates the uptake of cholesterol and fatty acids from plasma (Brown and Goldstein 1997), and glycerol3-phosphate acyltransferase, which initiates the synthesis of triglycerides (Ericsson et al. 1997). Expression of many other genes is elevated in cells that overexpress the nSREBPs, but it is not known whether these are direct targets of nSREBP action, or whether they are activated secondarily to the activation of other genes. The genes in this category include stearoyl CoA desaturase and lipoprotein lipase, among others (for review, see Brown and Goldstein 1997).

Three isoforms of SREBPs have been identified in human and animal cells. SREBP-1a and SREBP-1c are encoded by a single gene (Yokoyama et al. 1993; Hua et al. 1995). They differ in the first exon, which encodes an acidic transcriptional activating domain. SREBP-1a has a longer activation domain, and it is much more potent than SREBP-1c in activating transcription in all cells studied to date (Shimano et al. 1997a; Shimomura et al. 1997b). The third isoform of SREBP, designated SREBP-2, is produced by a different gene, and it contains a long acidic-activating domain resembling that of SREBP-1a (Hua et al. 1993). In general, all three SREBPs are capable of activating the same families of genes, but they do so with varying relative efficiencies. SREBP-2 preferentially favors the activation of the cholesterol biosynthetic pathway, whereas SREBP-1a and SREBP-1c tend to favor the fatty acid biosynthetic pathway (Horton et al. 1998; Pai et al. 1998).

The relative amounts of the SREBP-1a and SREBP-1c transcripts differ among cells and organs. SREBP-1a is the predominant transcript in growing cells, such as those in tissue culture. In the body of adult animals, the SREBP-1c transcript predominates in most organs, including liver and adipose tissue (Shimomura et al. 1997b).

In all animal cells, the SREBPs fulfill a crucial housekeeping function in regulating the lipid composition of membranes. In organs that are specialized for lipid metabolism, that is, liver and adipose tissue, the SREBPs play additional roles. In cultured adipose tissue cells, SREBP function has been studied most extensively by Kim and Spiegelman (1996), who focused on the ADD1/ SREBP-1c isoform. When the 3T3-L1 line of preadipocytes are caused to differentiate in tissue culture, the number of SREBP-1 gene transcripts rises markedly. The precise nature of these transcripts is controversial. In the 3T3-L1 cells studied in Dallas, these transcripts were exclusively of the SREBP-1a type (Shimomura et al. 1997b), whereas in Boston, the transcripts represented predominantly SREBP-1c (Kim et al. 1998a). When a truncated nuclear form of rat ADD1/SREBP-1c (amino acids 1-403) was overexpressed in 3T3-L1 cells by transfection, the amount of lipid accumulation was enhanced (Kim and Spiegelman 1996). In part, this was the result of the ability of nSREBP-1c to induce transcription of genes involved in fatty acid synthesis. Truncated nSREBP-1c also increased the production of an unidentified lipid ligand for peroxisome proliferator activator receptor- $\gamma$ (PPAR $\gamma)$, a known activator of adipocyte differentiation (Kim et al. 1998b). In response, there was increased transcription of adipocyte-specific genes, such as the fatty acid-binding protein aP2, adipsin, and lipoprotein lipase.

The function of nSREBPs has been studied in vivo in transgenic mice (Shimano et al. 1996 and 1997a; Horton et al. 1998). For these studies, the phosphoenolpyruvate carboxykinase (PEPCK) promoter was used to overexpress truncated dominant-positive nSREBPs that lack a membrane attachment domain and therefore enter the nucleus without a requirement for the regulated proteolytic step. When nSREBP-1a was expressed in this fashion, the livers of these animals overproduced cholesterol and triglyceride, and this led to a massive buildup of these lipids in this organ (Shimano et al. 1996). Paradoxically, the mass of triglyceride in white adipose tissue (WAT) declined even though the nSREBP-1a transgene was expressed at high levels in this organ. A similar experiment performed with nSREBP-1c led to a lesser accumulation of triglyceride in the liver, and there was no involution of adipose tissue (Shimano et al. 1997a). In SREBP-1 knockout mice (lacking both SREBP-1a and SREBP-1c), adipose tissue appeared normal, but the interpretation of this finding is unclear because there was a compensatory increase in SREBP-2 expression, which might have replaced the function of SREBP-1 (Shimano et al. 1997b). The SREBP-2 knockout is an embryonic lethal (J. Horton, H. Shimano, M.S. Brown, and J.L. Goldstein, unpubl.).

To further explore the potential role of SREBPs in adipose tissue, in the current studies we produced transgenic mice that express dominant-positive nSREBP-1c in white and brown fat through use of the well-character- 
ized adipocyte-specific aP2 enhancer/promoter (Ross et al. 1990). The transgenic mice displayed a syndrome that shares general features with CGL in humans (Seip and Trygstad 1996). The amount of WAT was markedly reduced, and the residual cells had an immature histologic appearance. This was associated with a marked reduction in most mRNAs that are normally abundant in WAT. The brown adipose tissue (BAT) of these animals was enlarged and converted to an appearance that resembled immature WAT. These findings were accompanied by a large fatty liver, profound insulin resistance, and hyperglycemia. These transgenic animals create a new model for the study of defects in adipose tissue development and function in mice.

\section{Results}

To achieve unregulated overexpression of nSREBP-1c in adipose tissue, we prepared a transgene encoding amino acids 1-436 of human SREBP-1c driven by a 5.4-kb DNA fragment containing the adipose-specific enhancer/promoter of the gene encoding aP2 (Ross et al. 1990). The truncated SREBP-1c lacks the membrane-attachment domain, and, therefore, it enters the nucleus directly without a requirement for proteolysis. We studied two lines of transgenic mice that were derived from independent founders. Northern blot analysis showed that WAT from line A mice contained approximately twofold more transgene-derived mRNA than did the line B mice (data not shown).

To eliminate any biological effects that might occur simply as a consequence of litters being born to diabetic transgenic females (see below), we propagated all lines through transgenic males. All of the transgenic animals used for the study were hemizygous for the transgene. Litters were of normal size at birth, and transgenic and control mice were indistinguishable. During the first week of life, transgenic mice could be identified on the basis of distended abdomens, bilobed interscapular humps, and runting. Transgenic pups actively nursed and consumed milk as evidenced by visual inspection, but some of the transgenic pups failed to thrive and died. The mortality of transgenic pups during the first 3 weeks of life was $\sim 20 \%$ for line A and $<5 \%$ for line B. Once the transgenic mice began consuming chow, most of them gained weight, and by 40 days of age their weight was similar to that of control littermates. A minority of the transgenic mice remained undersized throughout life.

\section{Gross changes in fat and liver of aP2-SREBP-1c transgenic mice}

Figure 1A shows a picture of an aP2-SREBP-1c transgenic mouse (line A) and a wild-type littermate at 7 days of age. In addition to its slightly runted appearance, the transgenic mouse shows a large mass in the interscapular region. A similar mass was present in all transgenic mice. On dissection, the mass was found to be composed of an enlarged bilobed, pale-appearing fat pad in the location where brown fat is usually found (Fig. 1B). The submandibular brown fat depot was also enlarged and pale in the transgenic mice. There was little omental or subcutaneous white fat in either wild-type or transgenic mice at this young age. The livers of the 7-day-old transgenic mice were massively enlarged and very pale, suggesting deposition of fat (Fig. 1C). Transgenic mice that survived the suckling period gradually gained weight and appeared normal except for the abdomen, which remained distended as a result of marked enlargement of the liver. At no time did the animals appear obese, and their body weights were not significantly different from nontransgenic littermates (see Table 1). The interscapular fat depot remained enlarged, but it did not become larger with age.

At 7-12 weeks of age, the transgenic mice showed marked enlargement of the liver, spleen, pancreas, and abdominal lymph nodes. No enlargement of the kidneys, heart, or skeletal muscles was noted. The omental fat, which was readily visible in wild-type littermates, was much smaller in the transgenic mice. Figure 2 shows the enlarged liver of a typical transgenic mouse (line A) at 12 weeks of age. The liver weighed twice as much as that of the wild type; it continued to be pale in appearance. In the wild-type mouse, the interscapular fat pad had the typical amber color of BAT. In the transgenic mouse, the bilobed interscapular fat pad was markedly enlarged, very firm, and white. On the other hand, the WAT of the transgenic mouse, as exemplified by the epididymal fat pad, was atrophic, and it weighed only $\sim 35 \%$ as much as the wild-type fat pad. The spleen, pancreas, and abdominal lymph nodes of the transgenic mice (line A) weighed 1.5- to 2 -fold more than the corresponding organs of littermate control mice.

\section{Histological changes in fat and liver of 8-day-old transgenic mice}

Histologic analysis of organs from 8-day-old mice re-
Figure 1. Photograph of 7-day-old wildtype male mouse (left) and a transgenic aP2SREBP-1c436 (line A) male littermate mouse (right). (A) Dorsal view of the mice, illustrating the enlargement of the interscapular brown fat pads in the transgenic mouse. (B) Exposed dorsal view of the interscapular brown fat pads. $(C)$ Exposed ventral view of the mice, illustrating the enlarged fatty liver in the transgenic mouse.
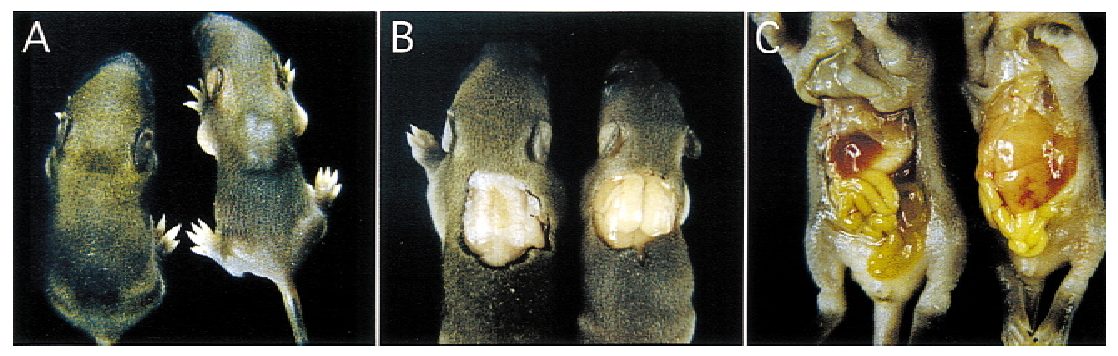
Table 1. Phenotypic comparison of wild-type and transgenic aP2-SREBP-1c436 mice

\begin{tabular}{|c|c|c|c|c|}
\hline \multirow[b]{2}{*}{ Parameter } & \multicolumn{2}{|c|}{ Line A (7 weeks old $)^{a}$} & \multicolumn{2}{|c|}{ Line B (11 weeks old $)^{a}$} \\
\hline & wild type & transgenic & wild type & transgenic \\
\hline Number of mice and sex & $3 \mathrm{M}, 4 \mathrm{~F}$ & $3 \mathrm{M}, 4 \mathrm{~F}$ & $2 \mathrm{M}, 2 \mathrm{~F}$ & $2 \mathrm{M}, 2 \mathrm{~F}$ \\
\hline Body weight (grams) & $20.7 \pm 1.0$ & $18.9 \pm 0.8$ & $28.8 \pm 1.6$ & $28.6 \pm 1.9$ \\
\hline Liver weight (grams) & $1.3 \pm 0.09$ & $2.4 \pm 0.1^{\ddagger}$ & $1.7 \pm 0.12$ & $2.5 \pm 0.12^{\dagger}$ \\
\hline Liver weight/body weight $(\%)$ & $5.9 \pm 0.30$ & $12.7 \pm 0.41^{\ddagger}$ & $5.9 \pm 0.52$ & $8.8 \pm 0.39^{\ddagger}$ \\
\hline Epididymal fat weight (grams) & $0.22 \pm 0.01$ & $0.064 \pm 0.003^{\ddagger}$ & $0.290 \pm 0.080$ & $0.154 \pm 0.012$ \\
\hline Epididymal fat/body weight $(\%)$ & $1.01 \pm 0.005$ & $0.37 \pm 0.04^{+}$ & $0.93 \pm 0.27$ & $0.48 \pm 0.04$ \\
\hline Brown fat weight (grams) & $0.027 \pm 0.002$ & $0.100 \pm 0.017^{\ddagger}$ & $0.049 \pm 0.007$ & $0.153 \pm 0.030^{\star}$ \\
\hline Brown fat/body weight $(\%)$ & $0.13 \pm 0.01$ & $0.51 \pm 0.09^{\ddagger}$ & $0.17 \pm 0.029$ & $0.49 \pm 0.09^{\star}$ \\
\hline Liver cholesterol content (mg/gram) & $2.7 \pm 0.13$ & $4.6 \pm 0.94$ & $2.3 \pm 0.07$ & $2.7 \pm 0.22$ \\
\hline Liver triglyceride content (mg/gram) & $7.9 \pm 0.42$ & $113 \pm 12.4^{\ddagger}$ & $8.9 \pm 2.0$ & $38 \pm 7.8^{+}$ \\
\hline Plasma FFA $(\mu \mathrm{M})$ & $771 \pm 89$ & $810 \pm 162$ & $1580 \pm 360$ & $1281 \pm 271$ \\
\hline Total plasma cholesterol (mg/dl) & $91 \pm 3.3$ & $148 \pm 8.2^{\ddagger}$ & $87 \pm 4.1$ & $96 \pm 4.4$ \\
\hline Total plasma triglycerides $(\mathrm{mg} / \mathrm{dl})$ & $74 \pm 1.9$ & $112 \pm 8.2^{+}$ & $123 \pm 19$ & $178 \pm 23$ \\
\hline
\end{tabular}

Each value represents the mean \pm S.E.M. of the indicated number of mice. Wild-type mice were littermates of the transgenic mice. Values in parentheses denote the level of statistical significance (Student's $t$-test): $\left({ }^{\star}\right) P<0.05 ;\left({ }^{\dagger}\right) P<0.01 ;\left({ }^{\ddagger}\right) P<0.001$.

a(M) Male; (F) female.

vealed the following alterations (Fig. 3). In the liver of a transgenic mouse (line A), the hepatocytes were swollen (Fig. 3B). The nuclei remained in the center of the cells, but the cytoplasm stained palely eosinophilic and contained numerous microvesicular vacuoles which, in rare hepatocytes, coalesced to form a distinct unilocular vacuole displacing the nucleus peripherally. The vacuolar change was uniform throughout the hepatic lobule. A similar histologic picture was seen in transgenic mice from line B (data not shown). The epididymal fat pad of an 8-day-old wild-type mouse contained a heterogeneous population of cells consisting of small, immature adipocytes (Fig. 3C, left) and mature adipocytes, each of which contained a large unilocular vacuole (Fig. 3C, right). In contrast, the white epididymal fat of the transgenic mouse consisted almost entirely of small immature adipocytes with brightly eosinophilic cytoplasm and a dis-

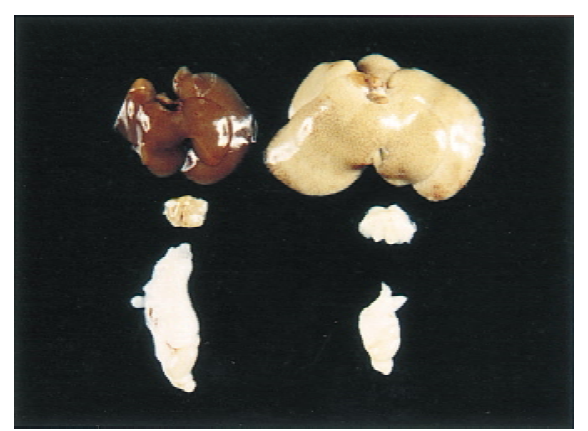

Figure 2. Liver, interscapular brown fat, epididymal white fat/ testis from a 3-month-old wild-type male mouse (left) and a transgenic aP2-SREBP-1c436 (line A) male littermate mouse (right). The wild-type and transgenic livers weighed 1.5 and 3.9 grams, respectively. The wild-type and transgenic interscapular fat weighed 58 and $110 \mathrm{mg}$, respectively. The wild-type and transgenic epididymal fat weighed 510 and $160 \mathrm{mg}$, respectively. tinct unilocular vacuole (Fig. 3D). The cytoplasm of brown adipocytes from the transgenic mouse contained large unilocular vacuoles similar to those of immature white adipocytes (Fig. 3F) in contrast to the small mul-

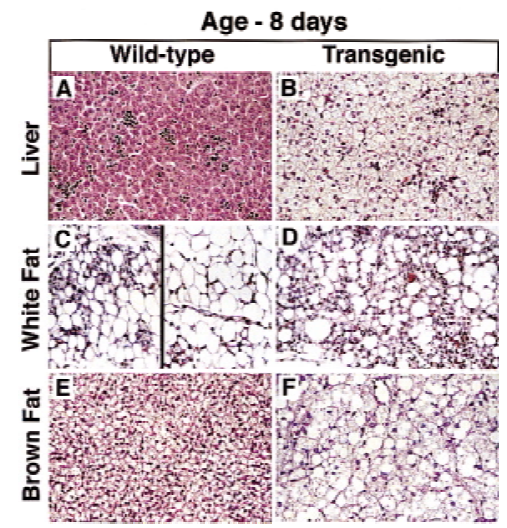

Figure 3. Histologic sections of liver $(A, B)$, white fat $(C, D)$, and brown fat $(E, F)$ from an 8-day-old wild-type male mouse and a transgenic aP2-SREBP-1c436 male littermate mouse (hematoxylin and eosin stain; magnification, $112 \times) .(A, B)$ Hepatocytes throughout the liver of the transgenic mouse are dramatically swollen. The cytoplasm stains palely eosinophilic and contains numerous microvesicular vacuoles. The alteration is uniform throughout the lobules. Scattered hematopoietic foci are present in both the wild-type and transgenic liver. $(C)$ White fat pad of a wild-type mouse contains a heterogeneous population of cells consisting of both small immature adipocytes (left) and mature adipocytes, each of which contains a large unilocular vacuole (right). (D) White fat of the transgenic mouse contains numerous, small immature adipocytes with brightly eosinophilic cytoplasm and a distinct unilocular vacuole. $(E, F)$ Adipocytes of the brown fat of the transgenic mouse are dramatically enlarged and stain palely. The cytoplasm is replaced by numerous small vacuoles that frequently coalesce to form large unilocular vacuoles, resembling those of immature white adipocytes. 
tilocular vacuoles characteristic of brown fat from the wild-type littermate (Fig. 3E).

\section{Histological changes in fat and liver of 40-day-old transgenic mice}

Figure 4 shows histologic sections of liver and fat from a 40-day-old transgenic mouse and its wild-type littermate. In the 40-day-old transgenic mouse, the hepatocellular swelling was not as dramatic as it was in the 8-dayold mouse, and it was confined to the centrolobular zone (Fig. 4B). There was no evidence of hepatitis or fibrosis. The epididymal fat pads of the 40-day-old wild-type mouse contained mature adipocytes of uniform size, each of which contained a characteristic unilocular fat droplet (Fig. 4C). In contrast, the epididymal white fat of the transgenic mouse contained a mixture of mature and immature adipocytes that varied widely in size (Fig. 4D). The immature adipocytes contained abundant eosinophilic cytoplasm, a round nucleus, and small distinct fat droplets. In some cells, the droplets coalesced to form the typical signet ring morphology. The mature adipocytes of the transgenic mouse each contained a distinct unilocular vacuole, but the cells exhibited more heterogeneity in size than did the mature adipocytes of the wild-type mouse. Some of the epididymal fat pads from transgenic mice showed histologic evidence of mild inflammation and fibrosis (data not shown). The brown fat of a wild-type mouse at 40 days consisted of small po-

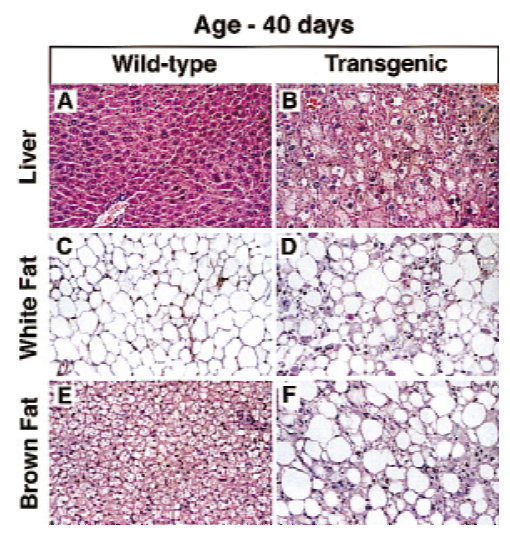

Figure 4. Histologic sections of liver $(A, B)$, white fat $(C, D)$, and brown fat $(E, F)$ from a 6-week-old wild-type mouse and a transgenic aP2-SREBP-1c436 littermate (hematoxylin and eosin stain; magnification, $112 \times) \cdot(A, B)$ Hepatocytes of the transgenic mouse are swollen and contain microvesicular vacuoles. $(C, D)$ Adipocytes in white fat of the transgenic mouse show marked heterogeneity of size. Admixed with the mature adipocytes are smaller, immature adipocytes with bright eosinophilic cytoplasm, a round nucleus, and a distinct unilocular vacuole. This is in contrast to the WAT from a wild-type mouse, which consists of adipocytes of uniform size filled with a large, unilocular vacuole. $(E, F)$ Interscapular brown fat of the transgenic mouse consists of markedly enlarged adipocytes containing large unilocular fat droplets. The interstitium shows signs of mild chronic inflammation. lygonal, multilocular adipocytes that were organized into lobules separated by connective tissue stroma (Fig. $4 \mathrm{E})$. In contrast, the majority of adipocytes in brown fat of the transgenic mice were markedly enlarged and contained a prominent unilocular fat droplet (Fig. 4F). Small numbers of immature adipocytes were scattered throughout the sections. The brown fat pads showed a proliferation of pericellular and interlobular connective tissue both surrounding the cells and within the septa, and there was evidence of mild inflammation (Fig. 4F).

\section{Comparison of metabolic parameters in wild-type and transgenic mice}

Table 1 compares relevant quantitative parameters in wild-type mice and littermates from transgenic lines A and $\mathrm{B}$. In general, the changes in the line B mice were in the same direction as the line A animals, but they were less profound. The body weights of the transgenic mice were normal, but the livers were significantly enlarged. The epididymal fat pads were small, and the interscapular brown fat was large. The hepatic content of triglyceride was markedly elevated. Hepatic cholesterol content was mildly increased, although the values did not reach statistical significance. Despite the marked fatty liver in 7-week-old line A mice, the plasma levels of albumin, aspartate aminotransferase, and bilirubin were normal (data not shown). The level of free fatty acids in the fed state were normal (Table 1). The plasma levels of cholesterol and triglycerides were mildly, but significantly elevated in the line A mice (7 weeks old), and there was a similar trend in line B (11 weeks old). In data not shown in Table 1, we studied four line A mice that were 9-11 months of age. The plasma triglyceride levels were markedly elevated (mean of $450 \mathrm{mg} / \mathrm{dl}$; range, 367565) when compared with five littermate controls (mean of $97 \mathrm{mg} / \mathrm{dl}$; range, 75-147).

\section{Expression of $m R N A$ s for target genes in fat and liver}

Blot-hybridization analysis of mRNA in the line A mice confirmed that the transgene was expressed in white and brown fat, but not in the liver (Fig. 5A). We also found no evidence of expression of the transgene in other tissues, including spleen, pancreas, and skeletal muscle (data not shown). In wild-type mice, immunoblots of nuclear extracts showed trace amounts of nSREBP-1a or nSREBP$1 \mathrm{c}$ in both white and brown fat. In contrast, nuclear extracts from white and brown fat of the line A transgenic mice showed abundant nSREBP-1c, which appeared to be manyfold above normal for these tissues. For comparative purposes, we estimate that the amount of nSREBP1c in adipose tissue nuclei in the transgenic mice was approximately twofold higher than the level in nuclei from livers of wild-type mice. The level of expression of nSREBP-1c in white and brown fat of line B mice was approximately one-half of that in line A mice /data not shown).

White and brown fat of the line A transgenic mice 


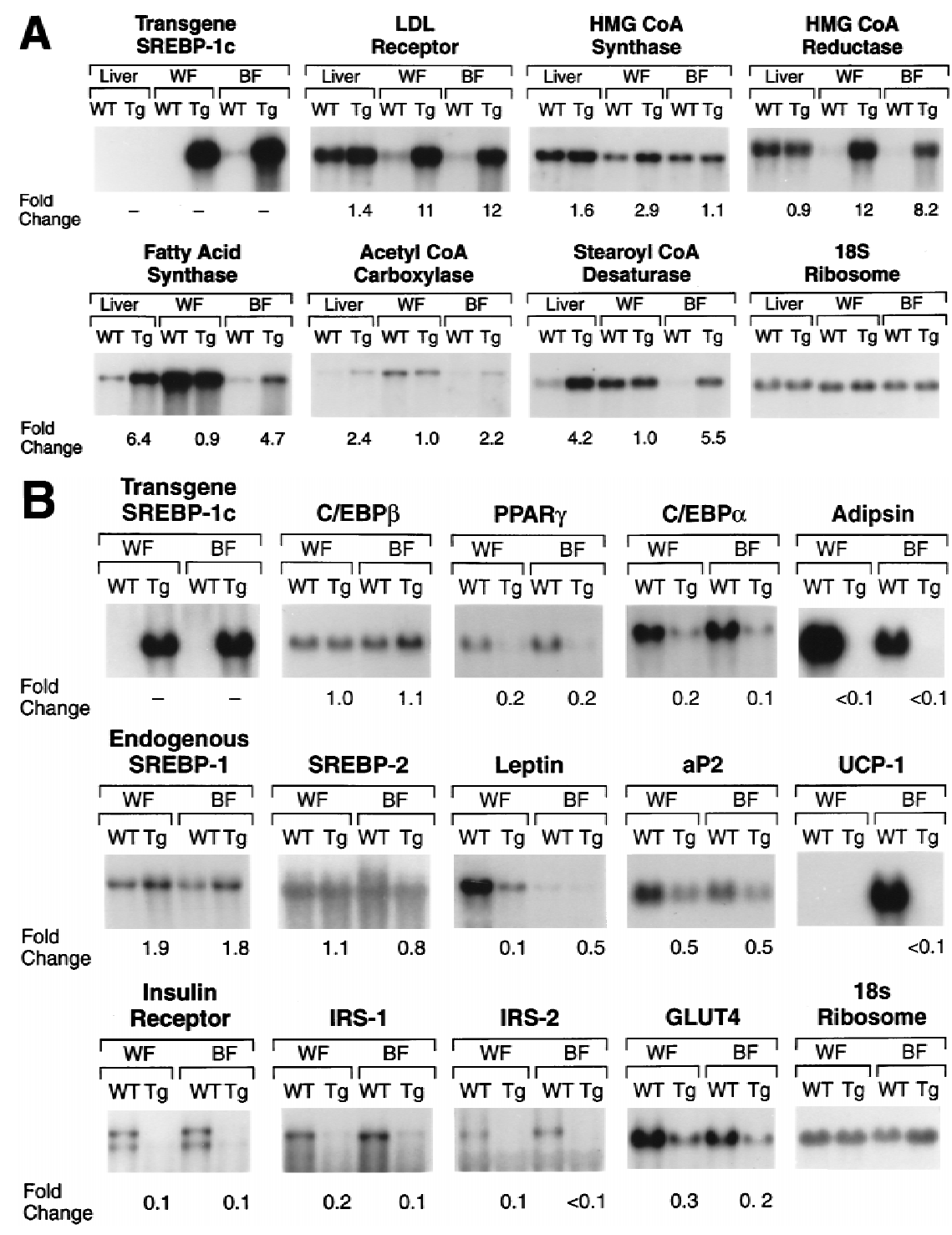

Figure 5. Amounts of various mRNAs in liver, white fat $(\mathrm{WF})$, and brown fat $(\mathrm{BF})$ of wild-type mice (WT) and transgenic aP2SREBP-1c436 (line A) mice (Tg) as measured by blot hybridization. The radioactivity in each band was quantified as described in Materials and Methods. The fold change in each mRNA of transgenic mice relative to that of wild-type mice was calculated after correction for loading differences by measuring the amount of $18 \mathrm{~S}$ rRNA. (A) Total RNA was isolated from two of the seven wild-type and two of the seven transgenic mice (line A) described in Table 1 . The RNA was pooled, and $10-\mu \mathrm{g}$ aliquots were subjected to electrophoresis and blot hybridization with the indicated ${ }^{32} \mathrm{P}$-labeled probe. The probe for stearoyl CoA desaturase (SCD) was a mouse SCD1 cDNA fragment that can detect both SCD1 and SCD2 mRNAs (Shimomura et al. 1998). (B) Total RNA was isolated from the remaining five wild-type and five littermate transgenic mice (line A) described in Table 1. The RNA was pooled, and 10$\mu \mathrm{g}$ aliquots were subjected to electrophoresis and blot hybridization with the indicated ${ }^{32} \mathrm{P}$-labeled probe. showed massive increases in the mRNA encoding the LDL receptor (11- and 12-fold, respectively) (Fig. 5A). Similar elevations were seen in the mRNA encoding HMG CoA reductase. The mRNA for HMG CoA synthase, another target of SREBPs, was elevated only in white fat and only by 2 .9-fold. In wild-type mice, the mRNAs of the fatty acid biosynthetic pathway (fatty acid synthase, acetyl CoA carboxylase, and stearoyl CoA desaturase) were much lower in brown fat than in white fat. The aP2-SREBP-1c436 transgene abolished this discrepancy, raising these mRNAs selectively in brown fat so that they became equal to the levels in white fat.

Even though the transgene was not expressed in liver, the livers of the transgenic mice showed a marked increase in the mRNA encoding fatty acid synthase (6.4fold) and significant increases in mRNAs encoding acetyl CoA carboxylase mRNA (2.4-fold) and stearoyl CoA desaturase (4.2-fold) (Fig. 5A). The other mRNA changes were all less than twofold. The possible reason for the increased mRNAs for fatty acid biosynthetic enzymes is discussed below.

Figure 5B shows a more extensive analysis of mRNA expression in white and brown fat of wild-type mice and their transgenic aP2-SREBP-1c436 littermates. Both fat depots of transgenic animals exhibited profound reductions in three mRNAs that are associated with fully differentiated adipocytes, that is, $\operatorname{PPAR} \gamma, \mathrm{C} / \mathrm{EBP} \alpha$, and adipsin. In wild-type mice, the amount of leptin mRNA was much higher in white fat than in brown fat. The transgenic animals exhibited a $90 \%$ reduction in leptin mRNA in white fat and a $50 \%$ reduction in the already low levels in brown fat. The expression of aP2 was reduced by $\sim 50 \%$ in both fat depots. In wild-type mice, the mRNA for uncoupling protein 1 (UCP1) was detectable only in BAT. This mRNA was reduced by $>95 \%$ to undetectable levels in the brown fat of the transgenic mice. White and brown fat showed profound $70 \%-90 \%$ reductions in four mRNAs that encode proteins that play roles 
in insulin action, that is, the insulin receptor, IRS-1, IRS2 , and glucose transporter-4 (GLUT4). The mRNA for endogenous SREBP-1 was elevated approximately twofold in white and brown fat of the transgenic mice, but there was no change in the mRNA for SREBP-2.

Two conspicuous mRNAs were elevated in white and BAT of transgenic mice, namely tumor necrosis factor- $\alpha$ (TNF $\alpha$ ) and Pref-1 (Fig. 6). Pref-1 is a cell surface molecule with epidermal growth factor repeats whose overexpression inhibits the terminal differentiation of adipocytes in tissue culture (Smas and Sul 1993). TNFo mRNA was not elevated in muscle, liver, or spleen of the transgenic mice.

\section{Measurements of plasma glucose, plasma insulin, and insulin sensitivity}

Nonfasting plasma insulin levels were elevated by 60fold in line A transgenic mice and 22-fold in line B (Fig. $7 \mathrm{~A}, \mathrm{C})$. In the line A transgenic mice, the blood sugar was markedly elevated (mean value $305 \mathrm{mg} / \mathrm{dl}$ ), but was not significantly elevated in the line B animals (Fig. 7B,D). In other experiments, we did observe elevated blood glucose levels in the line B animals (see legend to Fig. 8). Insulin tolerance tests showed that mice from line A and line B were markedly resistant to the glucose-lowering effect of exogenous insulin (Fig. 8). To date, we have studied 43 transgenic mice from lines $\mathrm{A}$ and $\mathrm{B}$, and all have had insulin resistance as determined by measurement of plasma insulin levels or insulin tolerance tests.

To determine whether skeletal muscle from the transgenic mice was resistant to insulin in vitro, we excised
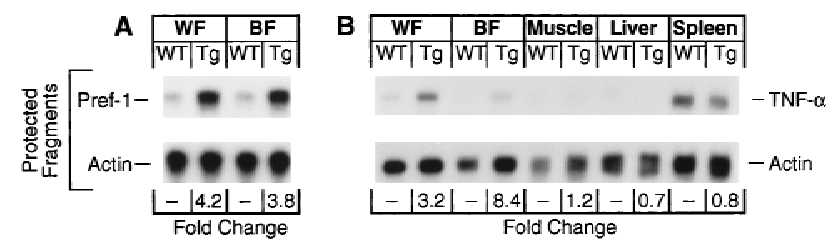

Figure 6. Changes in amounts of mRNA for Pref-1 $(A)$ and TNF $\alpha(B)$ in wild-type mice and transgenic aP2-SREBP-1c436 (line A) mice as measured by Rnase protection assay. Aliquots of total RNA $(20 \mu \mathrm{g})$ from pooled samples (see below) isolated from the indicated genotype were hybridized in solution for $10 \mathrm{~min}$ at $68^{\circ} \mathrm{C}$ to the ${ }^{32} \mathrm{P}$-labeled cRNA probes for Pref- 1 and TNF $\alpha$, all in the presence of a cRNA probe for $\beta$-actin as described in Materials and Methods. After RNase digestion, the protected fragments were separated by gel electrophoresis and exposed to film for $16 \mathrm{hr}$ at $-80^{\circ} \mathrm{C}$. The radioactivity in the gels was quantified, normalized to the $\beta$-actin signal, and expressed as the fold change relative to the mRNA level of wild-type mice. (A) Total RNA was isolated from the white fat (WF) and brown fat (BF) of five wild-type (WT) mice and five littermate transgenic (Tg) mice (line A) described in Fig. 5B. (B) Total RNA was isolated from the gastrocnemius muscle and spleen of three of the seven wild-type and four of the seven littermate transgenic mice (line A) described in Table 1. The total RNA from white fat and brown fat was obtained from an aliquot of the same sample in $A$. Total RNA of liver was isolated from two wild-type and two littermate transgenic mice (line A) described in Fig. 5A.
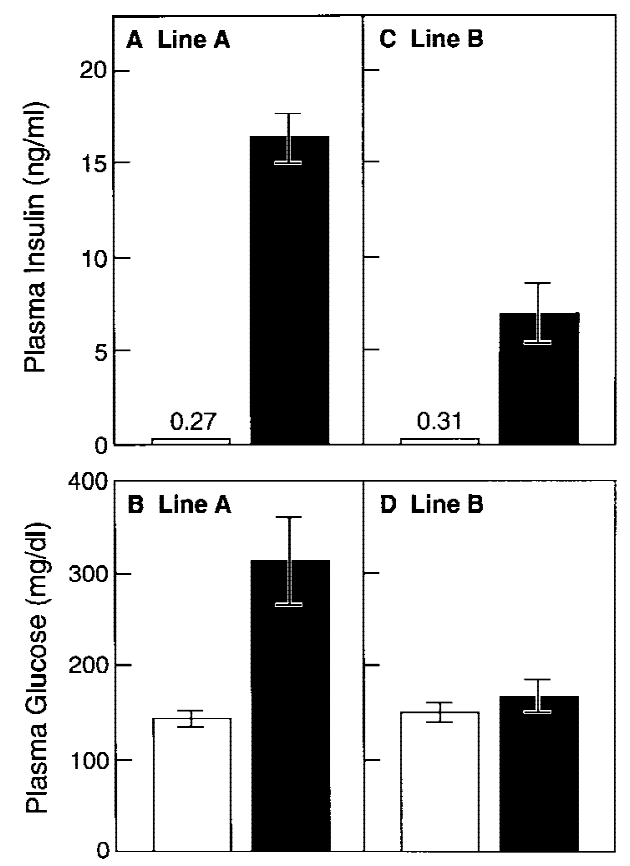

Figure 7. Plasma concentrations of insulin $(A, C)$ and glucose $(B, D)$ in wild-type (open bars) and two lines of transgenic aP2SREBP-1c436 (solid bars) mice. Blood was drawn in the earlyto-middle phase of the light cycle in the nonfasted state. Each value represents the mean \pm S.E.M. of seven mice $(A, B)$ or four mice $(C, D)$.

the soleus muscles from line A mice and wild-type littermates and incubated them with $\left[{ }^{3} \mathrm{H}\right] 2$-deoxyglucose in the absence or presence of insulin (10 nM or $100 \mathrm{nM}$ ) (Fig. 9). Insulin at both concentrations stimulated the uptake of $\left[{ }^{3} \mathrm{H}\right] 2$-deoxyglucose equally in both types of mice.

\section{Discussion}

Transgenic mice that overexpress nSREBP-1c in adipose tissue exhibit a distinct syndrome with five prominent features; paucity of white fat with signs of disordered differentiation; hypertrophic brown fat that assumes the appearance of immature white fat; massive fatty liver; insulin resistance; and diabetes mellitus. In contrast to all other mouse models of insulin resistance (Spiegelman et al. 1993; Spiegelman and Flier 1996), the aP2-SREBP1c transgenic mice were not obese. Rather, the phenotype appeared more analogous to human CGL (Seip and Trygstad 1996).

\section{Disordered differentiation of white fat}

At 8 days of age, even in wild-type mice, white fat was scanty and appeared immature. The appearance was similar in the transgenic littermates. By 6 weeks of age, the white fat of the wild-type animals had developed its normal mature appearance (Slavin 1979; Hausman and Richardson 1983). In contrast, the white fat of the 40- 


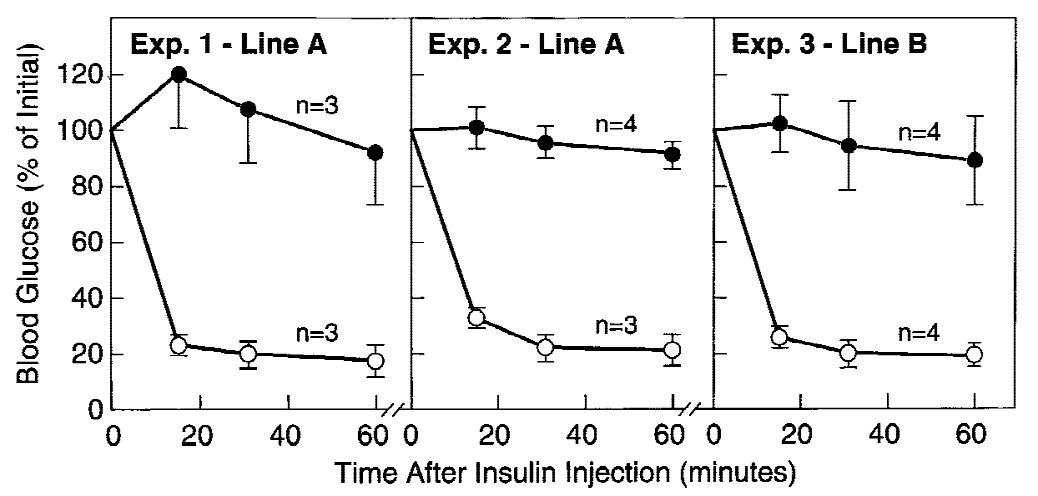

Figure 8. Insulin tolerance tests in wild-type (O) and transgenic aP2-SREBP-1c436 ( $)$ mice. Ad-libitum fed animals were injected intraperitoneally with human crystalline insulin in the middle of the light cycle as described in Materials and Methods, and blood was taken at the indicated time for measurement of glucose content. Results are expressed as percent of the plasma glucose concentration at zero time and are plotted as mean \pm S.E.M. of the indicated number of animals. The zero-time plasma glucose levels were as follows: Exp. 1, $164 \pm 23$ and $310 \pm 38 \mathrm{mg} / \mathrm{dl}$ in wild-type and transgenic mice, respectively; Exp. 2, $163 \pm 11$ and $412 \pm 72$; Exp. 3, $183 \pm 7$ and $279 \pm 91$. day-old transgenic mice continued to resemble the immature tissue that was seen at day 8 . The block in differentiation of WAT was not complete. On careful histologic examination, the epididymal fat pads of most transgenic animals contained islands of normal-appearing WAT. The weight of the epididymal fat pads was only $30 \%-40 \%$ of normal, and there was visual evidence for reduction of other white fat depots including omental and perinephric fat.

In the transgenic mice, the immature state of the WAT was reflected by the increased expression of the mRNA for Pref-1. This mRNA was cloned originally from cultured 3T3-L1 mouse preadipocytes on the basis of its differential expression in immature, but not mature, cells (Smas and Sul 1993). The current data show that Pref- 1 is present at low, but detectable, levels in epididymal fat pads of C57BL/6J $\times$ SJL strain mice at 7 weeks of age, and its level was elevated by fourfold in the transgenic mice. This was accompanied by a decline in many of the mRNAs that are usually found in mature adipose tissue. The decline was most marked for adipsin, which became undetectable (Fig. 5B). There were also major declines in mRNAs encoding $\operatorname{PPAR} \gamma, \mathrm{C} / \mathrm{EBP} \alpha$, and leptin, but a somewhat surprising persistence of the mRNA for aP2, which declined by only $50 \%$. This was fortuitous, because expression of the transgene was driven by the aP2 promoter, and the transgene would have been extinguished if transcription of this gene had been turned off.

The action of nSREBP-1c in blocking differentiation of adipocytes in mice appears to differ from its action in cultured mouse 3T3-L1 preadipocytes in which it increases adipocyte differentiation. This action is responsible for its alternative name, ADD1 (Tontonoz et al. 1993; Kim and Spiegelman 1996). Increased differentiation in tissue culture is believed to result, in part, from an SREBP-induced increase in the production of an activating ligand for PPAR $\gamma$, most likely a lipid (Kim et al. 1998b). Other activators of PPAR $\gamma$, such as thiazolidinediones, are known to enhance adipocyte differentiation (Spiegelman and Flier 1996). In adipose tissue of transgenic mice, the overexpression of nSREBP-1c paradoxically lowers the amount of mRNA encoding PPAR $\gamma$, along with other markers of adipocyte differentiation. It is possible that the differences between the in vivo and in vitro response relates to the stage of differentiation in which nuclear SREBP-1c is expressed.

\section{Disordered differentiation of brown fat}

The metabolic events underlying the development of BAT have not yet been elucidated either in vivo or in vitro. The current data suggest that it is possible to convert BAT into something resembling immature WAT by the forced overexpression of nSREBP-1c.

In normal mice, brown fat differentiates during embryonic development, whereas white fat completes its differentiation postnatally (Slavin 1979). At the time of birth, nSREBP-1c overexpression had already caused massive enlargement of brown fat depots. By 8 days of age, histologic studies showed that the brown fat depot contained markedly enlarged, fat-filled adipocytes.

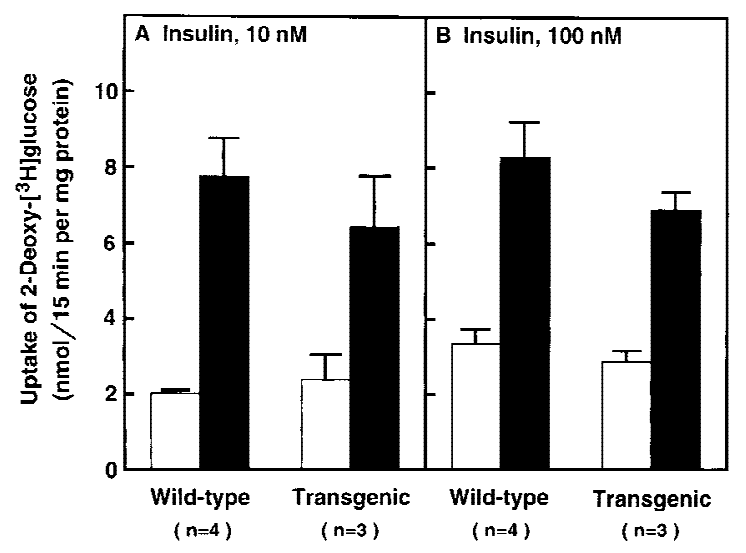

Figure 9. Uptake of $\left[{ }^{3} \mathrm{H}\right] 2$-deoxyglucose by isolated soleus muscle in wild-type and transgenic aP2-SREBP-1c436 mice. Soleus muscles from 12-week-old female mice (line A) were first incubated for $30 \mathrm{~min}$ with (solid bars) or without (open bars) the indicated concentration of insulin, followed by a 15-min incubation with $\left[{ }^{3} \mathrm{H}\right] 2$-deoxyglucose as described in Materials and Methods. Each value denotes the mean \pm S.E.M. of the indicated number of animals. Plasma glucose and insulin were measured in the mice used in B. Plasma glucose levels (mean \pm S.E.M.) were $170 \pm 12$ and $334 \pm 32 \mathrm{mg} / \mathrm{dl}$ for wild-type and transgenic mice, respectively. Plasma insulin levels were $0.07 \pm 0.02$ and $3.2 \pm 0.7 \mathrm{nM}$ for wild-type and transgenic mice, respectively. 
There was a complete disappearance of the mRNA for UCP1, the major differentiation marker of BAT (Fig. 5B). The mRNA for adipsin, normally found in mature brown and white fat, became undetectable in both fat tissues of the transgenic mice (Fig. 5B). In the brown fat of the transgenic mice, the mRNAs encoding enzymes of fatty acid synthesis rose so that the profile resembled that of the WAT in the same animals (Fig. 5A). The mRNA for Pref-1, a marker of immature WAT, rose by fourfold in the BAT depots of the transgenic mice (Fig. 6).

\section{Fatty liver}

The livers of the transgenic mice were overloaded with fat as early as 8 days of age. The mechanism for this fatty liver is almost certainly indirect. The aP2 enhancer/promoter does not support expression in liver (Ross et al. 1990), and we found no evidence of expression of the transgene in this organ. Nevertheless, the levels of mRNA encoding acetyl CoA carboxylase, fatty acid synthase, and stearoyl CoA desaturase were all elevated in liver despite a massive accumulation of triglyceride. The levels of plasma-free fatty acids were not elevated in the transgenic mice, supporting the notion that the hepatic triglycerides were produced from endogenously synthesized fatty acids. The most likely explanation lies in the massively elevated insulin levels in the transgenic mice. If the liver does not share the insulin resistance of peripheral tissues, it would be expected to respond by increasing the synthesis of fatty acids.

\section{Insulin resistance and diabetes mellitus}

The mechanism for the massive insulin resistance in the transgenic mice remains to be elucidated. Skeletal muscle is generally considered to be the major site for insulin-mediated glucose disposal (De Fronzo et al. 1981; McGarry et al. 1987). However, we were unable to find evidence for insulin resistence in skeletal muscle in these animals. Soleus muscles from the transgenic animals responded normally to insulin as measured by $\left[{ }^{3} \mathrm{H}\right] 2$-deoxyglucose uptake (Fig. 9). The levels of mRNA for the known effectors of insulin action, that is, the insulin receptor, IRS-1, IRS-2, and GLUT4, were normal in skeletal muscle of the aP2-SREBP-1c transgenic mice (data not shown). Therefore, we suspect that glucose uptake might be relatively normal in muscles of these mice and that the insulin resistance might result from a decrease in glucose uptake into adipose tissue. This would suggest that adipose tissue is the major target for the hypoglycemic action of insulin in mice.

The degree of insulin resistance in the aP2-SREBP-1c transgenic mice was as great as that seen in transgenic mice whose BAT has been ablated by tissue-specific expression of the diphtheria toxin A-chain (Lowell et al. 1993; Hamann et al. 1995). This raises the possibility that the insulin resistance in the aP2-SREBP-1c transgenics is the result of dysfunction of brown adipocytes as reflected by the disappearance of UCP1 mRNA. How- ever, several differences between the two-model systems suggest that the loss of function of BAT cannot be the complete explanation for the aP2-SREBP-1c phenotype. First, in the BAT-ablated animals, insulin resistance developed gradually during life in parallel with progressive obesity. At 6 weeks of age, insulin levels in the BATablated mice were not markedly elevated, but they became massively elevated at 22-26 weeks, at which time the animals were definitely obese. The livers were not noted to be markedly enlarged or fatty. In contrast, in the aP2-SREBP-1c transgenics insulin resistance was massive at 6 weeks in the absence of obesity, and the liver was fatty as early as 8 days.

\section{Relation between human CGL and lipodystrophy in aP2-nSREBP-1c transgenic mice}

The syndrome observed in the aP2-nSREBP-transgenic mice resembles some, but not all, of the features of human CGL (Seip and Trygstad 1996). Common aspects include disordered differentiation of WAT, profound insulin resistance, hyperglycemia, enlarged fatty liver, hypertriglyceridemia, and increased size of certain organs, including the pancreas and spleen. The block in differentiation of WAT is not as profound in the mice, as it is in the human disease, in which WAT is barely detectable. In affected humans and mice, the plasma levels of free fatty acids tend to be normal, and the individuals fail to develop ketoacidosis despite profound insulin resistance.

The most prominent difference between humans with CGL and the aP2-nSREBP-1c transgenic mice relates to the absence of a hypertrophic interscapular fat pad in the human disease. This may be attributable to the fact that humans seem to lack distinct brown fat depots analogous to the interscapular brown fat pad in mice, at least in adulthood (for review, see Foster 1992). Even in humans with CGL, some fat depots are spared. Studies by Garg et al. (1992) showed that certain fat depots are preserved in humans with CGL, including the palms, soles, tongue, breasts, and periarticular regions. These may have some analogy with the preserved interscapular fat depots in the aP2-nSREBP-1c transgenic animals.

The aP2-nSREBP-1c transgenic mice also fail to show the acceleration of linear growth or the hypertrophic cardiomyopathy that develops in some humans with CGL. The latter observation may relate to the relatively short period of observation of the mice. The oldest mice are 9-11 months of age. Further studies of the hearts of aging aP2-nSREBP-1c transgenic mice are planned.

\section{Underlying mechanism in the aP2-nSREBP-1c transgenic mice}

The mechanism by which overexpression of nSREBP-1c in adipose tissue interferes with adipocyte differentiation and causes insulin resistance remains to be elucidated. The most straightforward scenario postulates that nSREBP-1c increases the expression of antidifferentia- 
tion factors such as Pref- 1 and decreases the expression of prodifferentiation proteins such as $\mathrm{C} / \mathrm{EBP} \alpha$ and PPAR $\gamma$. Whether this is a direct effect of nSREBP-1c acting on these promoters, or whether it is secondary to the action of nSREBP-1c on other promoters, remains to be determined. The nSREBP-1c seems clearly to stimulate several SREBP-responsive promoters. The amount of LDL receptor mRNA was elevated by $>10$-fold in both white and brown fat and a similar elevation was seen in the mRNA for HMG CoA reductase. Yet, another SREBP-driven mRNA, HMG CoA synthase, was elevated only modestly. The transcriptional activity of nSREBP-1c must be highly dependent on other factors that allow it to selectively activate only a subset of SREcontaining promoters.

It is also possible that nSREBP-1c is disturbing adipocyte differentiation by acting negatively to block transcription of one or more key genes. This possibility arises because nSREBP-1c is a much less potent activator of transcription than is nSREBP-1a or nSREBP-2 (Shimano et al. 1997a; Pai et al. 1998). The aP2-nSREBP-1c transgene encodes a truncated version of SREBP-1c that enters the nucleus directly without a requirement for proteolysis. Hence, it is immune to the process of feedback regulation that limits the amount of nSREBP-1c in the nucleus of normal cells. Our immunoblots reveal that the amount of nSREBP-1c in adipose tissue nuclei of the transgenic mice is orders of magnitude higher than the amount that is normally in the nucleus of adipocytes. At such high levels, nSREBP-1c might form partially active heterodimers with nSREBP-1a or nSREBP-2, thereby limiting their activities. It also might bind indiscriminately to a subset of sterol regulatory elements or E boxes, thereby precluding access by more potent transcription factors.

Many of the hypotheses outlined above are susceptible to testing either in the transgenic mice or in tissue culture experiments. If the link can be found between nSREBP-1c overexpression and disordered adipose tissue differentiation, it might help us to understand not only CGL, but also other states of insulin resistance in humans such as noninsulin-dependent diabetes mellitus. It might also increase our understanding of the recently reported syndrome of lipodystrophy, insulin resistance, and hyperlipidemia that occurs in AIDS patients who are treated with inhibitors of the HIV protease (Carr et al. 1998; Viraben and Aquilina 1998).

\section{Related but distinct form of lipodystrophy}

Burant et al. (1997) recently described a delayed-onset form of lipodystrophy that arose when the adipose tissue of the mouse was genetically ablated by the targeted expression of a diphtheria toxin A transgene under control of the aP2 enhancer/promoter (aP2-DT mice). In contrast to the currently studied aP2-nSREBP-1c transgenic mice, the aP2-DT mice were phenotypically normal at birth (Ross et al. 1993) and showed no signs of lipodystrophy until 5-6 months of age, at which time the adipose tissue began to disappear (Burant et al. 1997). By
8-10 months of age, at a time when no WAT was visible, the animals showed the cardinal features of lipodystrophy, including insulin resistance, diabetes, fatty liver, and hypertriglyceridemia. Remarkably, oral treatment of the mice with troglitazone, a potent activator of PPAR $\gamma$ in adipose tissue (Spiegelman and Flier 1996), improved the hyperglycemia and normalized the insulin resistance even though the animals had no detectable adipose tissue (Burant et al. 1998). Whether or not the congenital lipodystrophy in the aP2-nSREBP-1c transgene mice will respond to troglitazone remains to be determined.

\section{Materials and methods}

\section{Assays and procedures}

The content of cholesterol and triglycerides in plasma and liver was measured as described (Yokode et al. 1990; Ishibashi et al. 1993). Plasma insulin levels were measured with a monoclonal anti-rat insulin radioimmunoassay by use of the Rat Insulin RIA Kit (Linco Research, St. Charles, MO). The measurements in Figures $7 \mathrm{C}$ and 8 were made in the authors' laboratory and those in Figure 7A by Ani Lytics (Gaithersburg, MD). Plasma glucose levels in Figures 7D and 8 were measured in the authors' laboratory by use of the Glucose (Trinder) 100 Kit (Sigma Diagnostics, St. Louis, MO). Plasma glucose measurements in Figure 7B were carried out by Ani Lytics with the Glucose/HK Kit (Boehringer Mannheim, Indianapolis, IN). Plasma-free fatty acids were measured by Ani Lytics with the Wako NEFA C Test Kit (Wako Chemicals, Richmond, VA). Sequencing reactions were performed on an Applied Biosystem model 373A DNA sequencer by the dideoxy chain termination method (Sambrook et al. 1989). For histological studies, the tissues were harvested, fixed in $10 \%$ (vol/vol) buffered formalin, dehydrated through graded ethanols, and embedded in paraffin. Sections were cut at $4 \mu \mathrm{m}$ and stained with hematoxylin and eosin. $2-\left[{ }^{3} \mathrm{H}(\mathrm{G})\right]$ deoxyD-glucose $(10 \mathrm{Ci} / \mathrm{mmole})$ and $\mathrm{D}-\left[1-{ }^{14} \mathrm{C}\right]$ mannitol $(55 \mathrm{mCi} /$ mmole) were obtained from American Radiolabeled Chemicals (St. Louis, MO). Human crystalline insulin was obtained from Lilly (Indianapolis, IN).

\section{Plasmid constructions}

An expression plasmid containing the mouse aP2 promoter/ enhancer (Ross et al. 1990) upstream of the sequences encoding amino acids 1-436 of human SREBP-1c (Shimano et al. 1997a) was constructed in three steps as follows. A 1.4-kb Sall fragment that encodes amino acids 1-436 of human SREBP-1c was excised from pPEPCK-SREBP-1c (Shimano et al. 1997a) and ligated into the SalI site of pCMV7 (Yokoyama et al. 1993), which contains a polyadenylation signal from the human growth hormone cDNA. A 1.7-kb SalI-SphI fragment encoding amino acids 1-436 of human SREBP-1c followed by the 3' polyadenylation signal was excised from the above plasmid, and the ends were filled in by DNA polymerase I (Klenow fragment). The resulting fragment was subcloned into the SmaI site of a pBluescript II $\mathrm{SK}(+)$ vector containing the $5.4-\mathrm{kb}$ promoter/enhancer of the mouse aP2 gene (kindly provided by Dr. Bruce M. Spiegelman; Ross et al. 1990). The final plasmid is designated paP2-SREBP1c436. The integrity of the plasmid was confirmed by DNA sequencing of the ligation junctions.

\section{Transgenic mice}

The technique used for generating transgenic mice has been 
described previously (Yokode et al. 1990). A 7.1-kb NotI-ClaI fragment of paP2-SREBP-1c436 was purified on a SeaKem GTG agarose gel (FMC Bioproducts, Rockland, ME) prior to microinjection into fertilized eggs from the C57BL/6J $\times$ SJL F2 strain of mice. A total of 452 fertilized eggs that were microinjected with the NotI-ClaI fragment of paP2-SREBP-1c436 survived to the two-cell stage. Among the 52 offspring, $11(19 \%)$ had integrated the transgene as determined by dot blot hybridization of DNA from tail homogenates. These 11 founder mice were subjected to partial adipectomy, and $82 \%$ produced the human SREBP1c436 transcript as determined by Northern blotting analysis. Mice with high levels of transgene expression were bred to C57BL/6J $\times$ SJL F1 mice, and two independently derived lines of transgenic mice, transgenic aP2-SREBP-1c436 (A and B), were established and characterized.

Mice were housed in colony cages and maintained on a 14-hr light/10-hr dark cycle. Transgenic and nontransgenic littermate mice were fed Teklad 4\% Mouse/Rat Diet no. 7001 from Harlan Teklad Premier Laboratory Diets (Madison, WI).

\section{Blot hybridization of RNA}

Plasmids containing sequences encoding mouse C/EBP $\beta$ and $\mathrm{C} / \mathrm{EBP} \alpha$ were obtained from Steven McKnight (Cao et al. 1991). A plasmid encoding mouse PPAR $\gamma$ was obtained from Ronald Evans (Kliewer et al. 1994). A plasmid-encoding mouse UCP1 was obtained from Leslie Kozak (Kozak et al. 1988). A plasmidencoding mouse IRS-2 was obtained from Morris White (Withers et al. 1998). The oligonucleotide probe used for analysis of mouse 18S rRNA was 5'-GCCGTGCGTACTTAGACATGCATG-3' (Torczynski et al. 1983).

cDNA probes for mouse adipsin, insulin receptor, IRS-1, and GLUT4 were prepared by RT-PCR by use of first-strand cDNA from mouse epididymal fat poly $(\mathrm{A})^{+} \mathrm{RNA}$, as described previously for other probes (Shimano et al. 1996). The PCR primers used to generate these probes were as follows. Adipsin: $5^{\prime}$ primer, 5'-CGAGGCCGGATTCTGGGTGGCCAG-3'; and 3' primer, 5'-TCGATCCACATCCGGTAGGATG-3' (Min et al. 1986). Insulin receptor: 5' primer, 5'-GTAGCCTGATCATCAACATCCG-3'; and 3' primer, 5' -CCTGCCCATCAAACTCTGTCAC-3' (Flores-Reveros et al. 1989). IRS-1: 5' primer, 5'ATGGCGAGCCCTCCGGATACCG-3'; and 3' primer, 5'CCTCTCCAACGCCAGAAGCTGCC-3' (Araki et al. 1994). GLUT4: 5' primer, 5'-CTCAGCAGCGAGTGACTGGGAC-3'; and 3' primer, 5' -CCCTGAGTAGGCGCCAATGAGG-3' (GenBank Accession D28561). All other probes have been described previously (Shimano et al. 1996, 1997a,b). cDNA probes were radiolabeled with $\left[\alpha-{ }^{32} \mathrm{P}\right] \mathrm{dCTP}(3000 \mathrm{Ci} / \mathrm{mmole})$ by use of the Megaprime DNA Labeling System (Amersham).

Total RNA was prepared with an RNA STAT-60 kit (TELTEST ${ }^{\prime} B^{\prime}$, Friendswood, TX). Total RNA from mice in each group was pooled, and aliquots of $10 \mu \mathrm{g}$ were subjected to Northern blot analysis. The filters were hybridized with the indicated ${ }^{32} \mathrm{P}$-labeled probe $\left(10^{6} \mathrm{cpm} / \mathrm{ml}\right)$ for $2 \mathrm{hr}$ at $65^{\circ} \mathrm{C}$ with Rapid-hyb buffer (Amersham Corp.), washed with $0.1 \%$ SDS $/ 0.2 \times$ SSC at $65^{\circ} \mathrm{C}$ for $30 \mathrm{~min}$, and exposed to Reflection NEF 496 film (Dupont-NEN, Boston, MA) with an intensifying screen at $-80^{\circ} \mathrm{C}$. Radioactivity was quantified by exposure of the filter to a BioImaging Analyzer with BAS1000 MacBus software (Fuji Medical Systems), and the results were normalized to the signal generated from $18 \mathrm{~S}$ rRNA.

\section{RNase protection assay}

cDNA fragments for mouse preadipocyte factor 1 (Pref-1) and mouse TNF $\alpha$ were amplified by PCR from first-strand cDNA prepared from 3T3-L1 preadipocyte poly(A) ${ }^{+}$RNA and mouse spleen 5'-stretch plus cDNA library (Clontech, Palo Alto, CA), respectively, with the following primers. Pref-1: $5^{\prime}$ primer, $5^{\prime}$ GCCGGGGGCTAGCCCCGTGCAGG-3'; and 3' primer, 5'AGGTGGTCATGTCAATCTTCTCGG-3' (Smas et al. 1993). $\mathrm{TNF} \alpha$; 5' primer, 5'-GCATGATCCGCGACGTGGAACTGGC$3^{\prime}$; and $3^{\prime}$ primer, 5'-GCTCAGCCACTCCAGCTGCTCC-3' (Caput et al. 1986). The 5' and $3^{\prime}$ primers were added with HindIII and EcoRI sites, respectively. First-strand cDNA was prepared by use of a SuperscriptII kit (GIBCO-BRL).

Amplified cDNA fragments were subcloned into the pGEM$3 Z \mathrm{Zf}(+)$ vector (Promega). After linearization of plasmid DNA with HindIII, antisense RNA was transcribed with $\left[\alpha-{ }^{32} \mathrm{P}\right] \mathrm{CTP}$ (800 Ci/mmole) by use of bacteriophage T7 RNA polymerase (Ambion, Austin, TX). Specific activities of the transcribed RNAs were measured in each experiment and were in the range of $1.7-2.6 \times 10^{9} \mathrm{cpm} / \mu \mathrm{g}$ for all RNAs except for $\beta$-actin RNA, which was $5.3-8.1 \times 10^{8} \mathrm{cpm} / \mu \mathrm{g}$.

Aliquots of total RNA (20 $\mu \mathrm{g}$ ) from each sample were subjected to the RNase protection assay with a HybSpeed RPA kit (Ambion, Inc.) as described previously (Shimomura et al. 1997a,b). Each assay tube contained a cRNA probe for the mRNA to be tested plus a cRNA probe complementary to the mRNA of $\beta$-actin. In preparing the probes, we adjusted the specific activity of the $\left[\alpha-{ }^{32} \mathrm{P}\right] \mathrm{CTP}$ to give a $\beta$-actin signal comparable to the test mRNAs. After digestion of RNase A/T1, protected fragments were separated on $8 \mathrm{M}$ urea $/ 4.8 \%$ polyacrylamide gels, and the gels were dried and subjected to autoradiography by use of reflection film and intensifying screens (Dupont, Wilmington, DE). The dried gels were also analyzed quantitatively with a Fuji PhosphorImager as described above. The level of $\beta$-actin mRNA in each RNA sample was used to normalize signals obtained for the test mRNAs.

\section{Insulin tolerance test}

Insulin tolerance tests were performed on fed 12-week-old (line A) and 14-week-old (line B) mice. Animals were injected intraperitoneally with $0.75 \mathrm{U} / \mathrm{kg}$ body weight ( $900 \mathrm{ng}$ per mouse) of human insulin. Blood was taken by retro-orbital puncture immediately before and at 15,30, and $60 \mathrm{~min}$ after injection for measurement of plasma glucose levels.

\section{Glucose uptake in isolated muscle}

Glucose uptake into isolated soleus muscle was measured by a modification of the method of Hansen et al. (1994). Nonfasted mice were killed by cervical dislocation, and both soleus muscles were rapidly removed and tied to stainless-steel clips by the tendons. Left and right muscles were used for measurement of basal and insulin-stimulated uptake of glucose, respectively. Incubations were carried out at $35^{\circ} \mathrm{C}$ with continuous shaking under an atmosphere of $95 \% \mathrm{O}_{2}$ and $5 \% \mathrm{CO}_{2}$ in $4 \mathrm{ml}$ of oxygenated Krebs-Ringer bicarbonate buffer at $\mathrm{pH} 7.4$ containing $0.1 \%$ (gram/vol) BSA, and $2 \mathrm{~mm}$ sodium pyruvate (KRBB buffer). The soleus muscles were preincubated for $40 \mathrm{~min}$ in KRBB buffer supplemented with $8 \mathrm{~mm}$ glucose and $32 \mathrm{~mm}$ mannitol to stabilize muscle metabolism. The muscles in each group were then sequentially incubated for $20 \mathrm{~min}$ with or without 10 or $100 \mathrm{~nm}$ human insulin; washed for $10 \mathrm{~min}$ with glucose-free KRBB buffer supplemented with $40 \mathrm{~mm}$ mannitol with or without insulin; incubated for $15 \mathrm{~min}$ with KRBB buffer supplemented with $1 \mathrm{~mm}\left[{ }^{3} \mathrm{H}\right] 2$-deoxyglucose (2064 or 2200 
dpm/nmole) and $39 \mathrm{~mm}\left[{ }^{14} \mathrm{C}\right]$ mannitol $(8 \mu \mathrm{Ci} / \mathrm{mmole})$ with or without insulin; washed for $30 \mathrm{~min}$ in ice-cold PBS containing $0.1 \%$ BSA; processed by boiling for $5 \mathrm{~min}$ in $1 \mathrm{ml}$ of $1 \mathrm{~N} \mathrm{NaOH}$ and neutralizing with $60 \mu \mathrm{l}$ of $5 \mathrm{~N} \mathrm{HCl}^{\text {; }}$ and subjected to scintillation counting for ${ }^{3} \mathrm{H}$ and ${ }^{14} \mathrm{C}$ radioactivities. $\left[{ }^{3} \mathrm{H}\right]$ Mannitol was used to correct for contaminating $\left[{ }^{3} \mathrm{H}\right] 2$-deoxyglucose in the extracellular space. Measurements of protein were made with the BCA Protein Assay Reagent kit (Pierce, Rockford, IL).

\section{Acknowledgments}

We thank our colleagues Hitoshi Shimano, Jay Horton, Sarah Comerford, Robert O'Doherty, Robert Grange, Michio Shimabukuro, Denis McGarry, and Roger Unger for helpful discussions and reagents; Richard Gibson, Beth Hinnart, Shan Maika, and Mario Villarreal for expert help with the animal studies; Scott Clark, Robin Craddock, and Debra Morgan for excellent technical assistance; and Robert Webb for invaluable assistance with histologic sectioning. This work was supported by grants from the National Institutes of Health (HL-20948), the Moss Heart Foundation, and the Perot Family Foundation. I.S. is the recipient of a Research Fellowship from the Manpei Suzuki Diabetes Foundation of Tokyo, Japan. S.I. is the recipient of a Research Fellowship from The National Institute of Health and Nutrition of Japan.

The publication costs of this article were defrayed in part by payment of page charges. This article must therefore be hereby marked 'advertisement' in accordance with 18 USC section 1734 solely to indicate this fact.

\section{References}

Araki, E., B.L. Haag, III, and C.R. Kahn. 1994. Cloning of the mouse insulin receptor substrate-1 (IRS-1) gene and complete sequence of mouse IRS-1. Biochim. Biophys. Acta 1221: 353-356.

Brown, M.S. and J.L. Goldstein. 1997. The SREBP pathway: Regulation of cholesterol metabolism by proteolysis of a membrane-bound transcription factor. Cell 89: 331-340.

Burant, C.F., S. Sreenan, K. Hirano, T.A.C. Tai, J. Lohmiller, J. Lukens, N.O. Davidson, S. Ross, and R.A. Graves. 1997. Troglitazone action is independent of adipose tissue. J. Clin. Invest. 100: 2900-2908.

Cao, Z., R.M. Umek, and S.L. McKnight. 1991. Regulated expression of three C/EBP isoforms during adipose conversion of 3T3-L1 cells. Genes \& Dev. 5: 1538-1552.

Caput, D., B. Beutler, K. Hartog, R. Thayer, S. Brown-Shimer, and A. Cerami. 1986. Identification of a common nucleotide sequence in the $3^{\prime}$-untranslated region of mRNA molecules specifying inflammatory mediators. Proc. Natl. Acad. Sci. 83: $1670-1674$.

Carr, A., K. Samaras, S. Burton, M. Law, J. Freund, D.J. Chisholm, and D.A. Cooper. 1998. A syndrome of peripheral lipodystrophy, hyperlipidaemia and insulin resistance in patients receiving HIV protease inhibitors. AIDS 12: F51-F58.

DeFronzo, R.A., E. Jacot, E. Jequier, E. Maeder, J. Wahren, and J.P. Felber. 1981. The effect of insulin on the disposal of intravenous glucose: Results from indirect calorimetry and hepatic and femoral venous catheterization. Diabetes 30: 1000-1007.

Ericsson, J., S.M. Jackson, J.B. Kim, B.M. Spiegelman, and P.A. Edwards. 1997. Identification of glycerol-3-phosphate acyltransferase as an adipocyte determination and differentiation factor 1- and sterol regulatory element-binding protein- responsive gene. J. Biol. Chem. 272: 7298-7305.

Flores-Riveros, J.R., E. Sibley, T. Kastelic, and M.D. Lane. 1989. Substrate phosphorylation catalyzed by the insulin receptor tyrosine kinase. J. Biol. Chem. 264: 21557-21572.

Foster, D.W. 1992. Eating disorders: Obesity, anorexia nervosa, and bulimia nervosa. In Williams textbook of endocrinology (ed. J.D. Wilson and D.W. Foster), pp. 1335-1365. W.B. Saunders Company, Philadelphia, PA.

Garg, I., J.L. Fleckenstein, R.M. Peshok, and S.M. Grundy. 1992. Peculiar distribution of adipose tissue in patients with congenital generalized lipodystrophy. J. Clin. Endocrinol. Metab. 75: 358-361.

Hamann, A., H. Benecke, Y. Le Marchand-Brustel, V.S. Susulic, B.B. Lowell, and J.S. Flier. 1995. Characterization of insulin resistance and NIDDM in transgenic mice with reduced brown fat. Diabetes 44: 1266-1273.

Hansen, P.S., E.A. Gulve, and J.O. Holloszy. 1994. Suitability of 2-deoxyglucose for in vitro measurement of glucose transport activity in skeletal muscle. J. Appl. Physiol. 76: 979985.

Hausman, G.J. and R.L. Richardson. 1983. Cellular and vascular development in immature rat adipose tissue. J. Lipid Res. 24: $522-532$.

Horton, J.D., I. Shimomura, M.S. Brown, R.E. Hammer, J.L. Goldstein, and H. Shimano. 1998. Activation of cholesterol synthesis in preference to fatty acid synthesis in liver and adipose tissue of transgenic mice overproducing SREBP-2. J. Clin. Invest. 101: 2331-2339.

Hua, X., C. Yokoyama, J. Wu, M.R. Briggs, M.S. Brown, J.L. Goldstein, and X. Wang. 1993. SREBP-2, a second basic-helix-loop-helix-leucine zipper protein that stimulates transcription by binding to a sterol regulatory element. Proc. Nat1. Acad. Sci. 90: 11603-11607.

Hua, X., J. Wu, J.L. Goldstein, M.S. Brown, and H.H. Hobbs. 1995. Structure of human gene encoding sterol regulatory element binding protein-1 (SREBF1) and localization of SREBF1 and SREBF2 to chromosomes $17 \mathrm{p} 11.2$ and $22 \mathrm{q} 13$. Genomics 25: 667-673.

Ishibashi, S., M.S. Brown, J.L. Goldstein, R.D. Gerard, R.E. Hammer, and J. Herz. 1993. Hypercholesterolemia in LDL receptor knockout mice and its reversal by adenovirus-mediated gene delivery. J. Clin. Invest. 92: 883-893.

Kim, J.B. and B.M. Spiegelman. 1996. ADD1/SREBP1 promotes adipocyte differentiation and gene expression linked to fatty acid metabolism. Genes \& Dev. 10: 1096-1107.

Kim, J.B., G.D. Spotts, Y.-D. Halvorsen, H.-M. Shih, T. Ellenberger, H.C. Towle, and B.M. Spiegelman. 1995. Dual DNA binding specificity of ADD1/SREBP1 controlled by a single amino acid in the basic helix-loop-helix domain. Mol. Cell. Biol. 15: 2582-2588.

Kim, J.B., P. Sarraf, M. Wright, K.M. Yao, E. Mueller, G. Solanes, B.B. Lowell, and B.M. Spiegelman. 1998a. Nutritional and insulin regulation of fatty acid synthetase and leptin gene expression through ADD1/SREBP1. J. Clin. Invest. 101: 1-9.

Kim, J.B., H.M. Wright, M. Wright, and B.M. Spiegelman. 1998b. ADD1/SREBP1 activates PPAR gamma through the production of endogenous ligand. Proc. Natl. Acad. Sci. 95: 43334337.

Kliewer, S.A., B.M. Forman, B. Blumberg, E.S. Ong, U. Borgmeyer, D.J. Mangelsdorf, K. Umesono, and R.M. Evans. 1994. Differential expression and activation of a family of murine peroxisome proliferator-activated receptors. Proc. Nat1. Acad. Sci. 91: 7355-7359.

Kozak, L.P., J.H. Britton, U.C. Kozak, and J.M. Wells. 1988. The mitochondrial uncoupling protein gene. I. Biol. Chem. 263: $12274-12277$. 
Lowell, B.B., V. S-Susulic, A. Hamann, J.A. Lawitts, J. HimmsHagen, B.B. Boyer, L.P. Kozak, and J.S. Flier. 1993. Development of obesity in transgenic mice after genetic ablation of brown adipose tissue. Nature 366: 740-742.

McGarry, J.D., M. Kuwajima, C.B. Newgard, and D.W. Foster. 1987. From dietary glucose to liver glycogen: The full circle round. Annu. Rev. Nutr. 7: 51-73.

Min, H.Y. and B.M. Spiegelman. 1986. Adipsin, the adipocyte serine protease: Gene structure and control of expression by tumor necrosis factor. Nucleic Acids Res. 14: 8879-8892.

Pai, J.-t., O. Guryev, M.S. Brown, and J.L. Goldstein. 1998. Differential stimulation of cholesterol and unsaturated fatty acid biosynthesis in cells expressing individual nuclear sterol regulatory element binding proteins. J. Biol. Chem. 273: 26138-26148.

Parraga, A., L. Bellsolell, A.R. Ferre-D'Amare, and S.K. Burley. 1998. Co-crystal structure of sterol regulatory element binding protein 1a at 2.3 A resolution. Structure 6: 661-672.

Ross, S.R., R.A. Graves, A. Greenstein, K.A. Platt, H.-L. Shyu, B. Mellovitz, and B.M. Spiegelman. 1990. A fat-specific enhancer is the primary determinant of gene expression for adipocyte P2 in vivo. Proc. Natl. Acad. Sci. 87: 9590-9594.

Ross, S.R., R.A. Graves, and B.M. Spiegelman. 1993. Targeted expression of a toxin gene to adipose tissue: Transgenic mice resistant to obesity. Genes \& Dev. 7: 1318-1324.

Sambrook, J., E.F. Fritsch, and T. Maniatis. 1989. Molecular cloning: A laboratory manual Cold Spring Harbor Laboratory Press, Cold Spring Harbor, NY.

Seip, M. 1959. Lipodystrophy and gigantism with associated endocrine manifestations. A new diencephalic syndrome? Acta Paediatr. Scand. 48: 555-574.

Seip, M. and O. Trygstad. 1996. Generalized lipodystrophy, congenital and acquired (lipoatrophy). Acta Paediatr. Scand. Suppl. 413: 2-28.

Shimano, H., J.D. Horton, R.E. Hammer, I. Shimomura, M.S Brown, and J.L. Goldstein. 1996. Overproduction of cholesterol and fatty acids causes massive liver enlargement in transgenic mice expressing truncated SREBP-1a. J. Clin. Invest. 98: 1575-1584.

Shimano, H., J.D. Horton, I. Shimomura, R.E. Hammer, M.S. Brown, and J.L. Goldstein. 1997a. Isoform 1c of sterol regulatory element binding protein is less active than isoform $1 \mathrm{a}$ in livers of transgenic mice and in cultured cells. J. Clin. Invest. 99: 846-854.

Shimano, H., I. Shimomura, R.E. Hammer, J. Herz, J.L. Goldstein, M.S. Brown, and J.D. Horton. 1997b. Elevated levels of SREBP-2 and cholesterol synthesis in livers of mice homozygous for a targeted disruption of the SREBP-1 gene. J. Clin. Invest. 100: 2115-2124.

Shimomura, I., H. Shimano, J.D. Horton, J.L. Goldstein, and M.S. Brown. 1997a. Differential expression of exons 1a and $1 \mathrm{c}$ in mRNAs for sterol regulatory element binding protein-1 in human and mouse organs and cultured cells. J. Clin. Invest. 99: 838-845.

Shimomura, I., Y. Bashmakov, H. Shimano, J.D. Horton, J.L. Goldstein, and M.S. Brown. 1997b. Cholesterol feeding reduces nuclear forms of sterol regulatory element binding proteins in hamster liver. Proc. Natl. Acad. Sci. 94: 1235412359.

Shimomura, I., H. Shimano, B.S. Korn, Y. Bashmakov, and J.D. Horton. 1998. Nuclear sterol regulatory element binding proteins activate genes responsible for entire program of unsaturated fatty acid biosynthesis in transgenic mouse liver. J. Biol. Chem. (in press).

Slavin, B.G. 1979. Fine structural studies on white adipocyte differentiation. Anat. Rec. 195: 63-72.
Smas, C.M. and H.S. Sul. 1993. Pref-1, a protein containing EGFlike repeats, inhibits adipocyte differentiation. Cell 73: 725734.

Spiegelman, B.M. and J.S. Flier. 1996. Adipogenesis and obesity: Rounding out the big picture. Cell 87: 377-389.

Spiegelman, B.M., L. Choy, G.S. Hotamisligil, R.A. Graves, and P. Tontonoz. 1993. Regulation of adipocyte gene expression in differentiation and syndromes of obesity/diabetes. J. Biol. Chem. 268: 6823-6826.

Tontonoz, P., J.B. Kim, R.A. Graves, and B.M. Spiegelman. 1993. ADD1: A novel helix-loop-helix transcription factor associated with adipocyte determination and differentiation. Mol. Cell. Biol. 13: 4753-4759.

Torczynski, R., A.P. Bollon, and M. Fuke. 1983. The complete nucleotide sequence of the rat $18 \mathrm{~S}$ ribosomal RNA gene and comparison with the respective yeast and frog genes. Nucleic Acids Res. 11: 4879-4890.

Viraben, R. and C. Aquilina. 1998. Indinavir-associated lipodystrophy. AIDS 12: F37-F39.

Withers, D.J., J.S. Gutierrez, H. Towery, D.J. Burks, J.-M. Ren, S. Previs, Y. Zhang, D. Bernal, S. Pons, G.I. Shulman, S. Bonner-Weir, and M.F. White. 1998. Disruption of IRS-2 causes type 2 diabetes in mice. Nature 391: 900-904.

Yokode, M., R.E. Hammer, S. Ishibashi, M.S. Brown, and J.L. Goldstein. 1990. Diet-induced hypercholesterolemia in mice: Prevention by overexpression of LDL receptors. Science 250: 1273-1275.

Yokoyama, C., X. Wang, M.R. Briggs, A. Admon, J. Wu, X. Hua, J.L. Goldstein, and M.S. Brown. 1993. SREBP-1, a basic helixloop-helix leucine zipper protein that controls transcription of the LDL receptor gene. Cell 75: 187-197. 


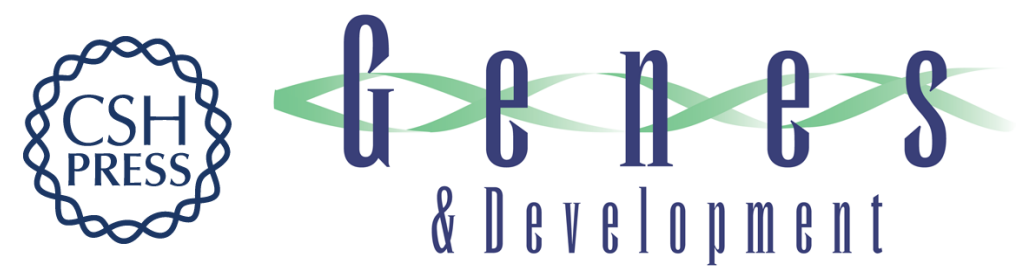

\section{Insulin resistance and diabetes mellitus in transgenic mice expressing nuclear SREBP-1c in adipose tissue: model for congenital generalized lipodystrophy}

lichiro Shimomura, Robert E. Hammer, James A. Richardson, et al.

Genes Dev. 1998, 12:

Access the most recent version at doi:10.1101/gad.12.20.3182

References This article cites 46 articles, 20 of which can be accessed free at:

http://genesdev.cshlp.org/content/12/20/3182.full.html\#ref-list-1

License

Email Alerting

Receive free email alerts when new articles cite this article - sign up in the box at the top

Service

right corner of the article or click here.

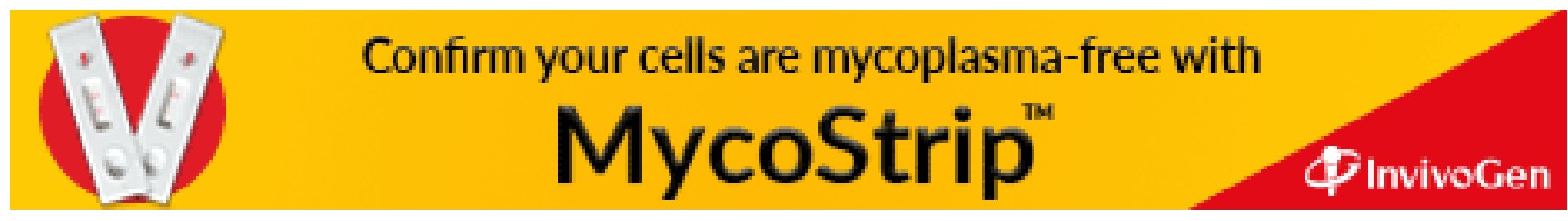

